\title{
Kualitas Produk Dan Dampaknya Terhadap Keputusan Pembelian Gitar Aristone Pada CV. Arista Bandung
}

\author{
${ }^{1}$ Yani Restiani Widjaja, ${ }^{2}$ Gani Nurdiyana \\ ${ }^{1,2}$ Universitas Bina Sarana Informasi Bandung \\ yani.yrw@bsi.ac.id
}

\begin{abstract}
ABSTRAK
Penelitian ini bertujuan untuk mengetahui besarnya pengaruh kualitas produk terhadap keputusan pembelian serta untuk menguji apakah ada pengaruh signifikan antara kualitas produk dan keputusan pembelian pada produk gitar Aristone di Kota Bandung. Metode penelitian yang digunakan adalah metode penelitian analisis verifikatif, dengan melakukan uji validitas, uji reliabilitas, analisis regresi sederhana, analisis koefisien sederhana, dan analisis determinasi. Berdasarkan uji statistik yang dilakukan, diperoleh uji t yang menunjukan bahwa terdapat pengaruh yang signifikan variabel kualitas produk terhadap keputusan pembelian konsumen pada produk gitar Aristone di Kota Bandung. Dari hasil analisis koefisien korelasi diperoleh bahwa apabila kualitas produk meningkat, maka akan diikuti oleh kenaikan keputusan pembelian konsumen, begitu juga sebaliknya. Tingkat hubungan antara kualitas produk dengan keputusan pembelian konsumen diinterpretasikan kuat. Hasil koefisien determinasi menunjukkan adanya kontribusi dari kualitas produk (X) terhadap keputusan pembelian konsumen (Y) .
\end{abstract}

Kata kunci: Kualitas produk, Keputusan Pembelian

\begin{abstract}
This study aims to determine the magnitude of the effect of product quality on purchasing decisions and to test whether there is a significant influence between product quality and purchasing decisions on Aristone guitar products in Bandung. The research method used is the research method of verification analysis, by conducting validity test, reliability test, simple regression analysis, simple coefficient analysis, and determination analysis. Based on statistical tests conducted, t test showed that there is a significant effect of product quality variables on consumer purchasing decisions on Aristone guitar products in Bandung. From the results of the correlation coefficient analysis is obtained that if the product quality increases, it will be followed by an increase in consumer purchasing decisions, and vice versa. The degree of relationship between product quality and consumer purchase decisions is strongly interpreted. The coefficient of determination shows the contribution of product quality $(X)$ to consumer purchase decision $(Y)$.
\end{abstract}

Keywords: product quality, purchase decision.

\section{PENDAHULUAN}

Pada zaman modern ini perkembangan industri musik sangat pesat, khususnya di Indonesia. Tidak dapat dipungkiri Persaingan antar pasar industri musik semakin hari semakin kompetitif. Hal ini terbukti dengan banyaknya model dan jenis spare part yang diperuntukan untuk para musisi beredar baik produksi dalam negeri maupun produksi luar negeri. Membanjirnya produk di pasaran mempengaruhi sikap seseorang terhadap pembelian dan pemakaian barang. Pembelian suatu produk bukan lagi untuk memenuhi kebutuhan (need), melainkan karena keinginan (want). Ditambah dengan ditemukannya konsumen yang memutuskan memilih menggunakan produk tertentu dalam hal ini adalah gitar dalam rangka memperjelas identitas diri agar dipandang baik dalam komunitas tertentu terutama untuk golongan musisi dan sesama pemusik.

Berdasarkan hal tersebut tidak menutup kemungkinan para produsen alat musik mengambil peluang ini untuk memasarkan produknya baik itu produsen lokal maupun produsen asing. Dalam penerapannya tidak jauh berbeda dengan proses pengembangan pemasaran produk lainnya. Para produsen tersebut harus dapat mengembangkan konsep pemasaran yang berorientasi pada konsumen. Mereka harus dapat memenuhi tuntutan konsumen dalam menyediakan barang atau jasa yang lebih baik serta dapat memuaskan kebutuhan dan keinginan para konsumen. Harus ada usaha yang 
dilakukan perusahaan untuk memenuhi kebutuhan konsumen sekaligus memenangkan persaingan.

Perusahaan harus mempersiapkan strategi pemasaran yang tepat untuk produknya. Produk yang ditawarkan ke pasar harus mendapatkan perhatian untuk dibeli, digunakan, atau dikonsumsi agar memenuhi keinginan dan kebutuhan calon konsumen. Berdasarkan wawancara dengan founder gitar Aristone, dalam memilih produk, konsumen tentu saja akan terlebih dahulu melihat merek, bentuk, model, warna, kualitas dan sebagainya. Tidak hanya itu saja, konsumen pun harus mempertimbangkan efisiensi dari produk tersebut untuk mengatasi kebutuhan konsumen, Sehingga konsumen harus benar-benar teliti dan memikirkan, apakah produk tersebut bisa menjawab keinginan dan kebutuhan konsumen. Berdasarkan hal tersebut, maka analisis mengenai keputusan pembelian sangat penting dilakukan oleh perusahaan-perusahaan yang memasarkan produk alat musik. Hal tersebut perlu dilakukan agar perusahaan dapat selalu meningkatkan volume penjualan yaitu melalui analisa faktor atau atribut apa saja yang menjadi keputusan konsumen dalam membeli alat musik. Karena masing-masing konsumen memiliki motif yang berbeda dalam melakukan pembelian.

Perilaku konsumen menjadi salah satu faktor yang perlu dipertimbangkan dalam usaha pemasaran produk. Strategi pemasaran yang tepat merupakan salah satu cara untuk mencapai tujuan perusahaan yaitu dengan mengetahui kebutuhan dan keinginan konsumen sehingga tercipta produk yang tepat.

Dengan demikian peningkatan volume penjualan dan memenangkan persaingan dapat tercapai. Begitu juga dilakukan para produsen alat musik seiring dengan permintaan yang meningkat. Persaingan tersebut terlihat dalam pertumbuhan industri alat musik di Indonesia salah satunya adalah alat musik gitar. Alat musik ini adalah instrumen musik yang paling familiar. Oleh karena itu, banyak bermunculan berbagai macam gitar dengan aneka merk, harga dan variasi model yang disertai keunggulannya masing-masing. Adapun jenis - jenis gitar antara lain adalah gitar klasik, gitar akustik dan gitar elektrik.

Dalam persaingan produk gitar terdapat beberapa jenis dan merk yang sampai saat ini bersaing di pasaran. Salah satunya adalah Gitar merek Aristone dari CV. ARISTA di Bandung. Faktor yang menyebabkan seorang pemusik memilih Gitar buatan Aristone sebagai pilihannya. Mulai dari desain, harga yang terjangkau, kualitas dan kuantitas, sampai dengan beberapa faktor lainnya yang tidak kalah dengan produk lainnya. Pada umumnya aspek produk menjadi faktor utama yang menjadi pertimbangan calon konsumen sebelum melakukan pembelian. Keaneka ragaman warna produk yang ditawarkan, kualitas dan desain yang menarik juga berpengaruh pada persepsi calon konsumen mengenai produk tersebut. Selain itu, aspek lokasi dan distribusi untuk mempermudah konsumen dalam memperoleh produk tersebut bisa jadi juga mempengaruhi konsumen sebelum melakukan keputusan pembelian produk Gitar merek.

Seiring perkembangan perekonomian dan teknologi yang maju,gitar Aristone dapat menarik perhatian masyarakat luas, dilihat dari desain yang variatif dengan tampilan warna yang lebih dinamis,dan harga yang terjangkau Gitar Aristone cocok digunakan oleh kalangan muda. Hal ini menjadikan perusahaan-perusahaan instrumen saling berlomba untuk menghasilkan alat musik yang mampu memenuhi kebutuhan, keinginan dan selera konsumen serta menawarkan harga yang bisa dijangkau oleh konsumen pada umumnya.

Kualitas produk dan desain produk berpengaruh, dalam keputusan pembelian, masalah desain dari suatu produk telah menjadi salah satu faktor yang perlu mendapatkan perhatian serius dari manajemen khususnya tim pengembangan produk baru, karena sasaran konsumen yang dituju tidak sedikit yang mulai mempersoalkan masalah desain suatu produk yang mampu memenuhi kebutuhan.

Desain produk gitar saat ini sangat beraneka ragam, mengingat perkembangan kebutuhan dan permintaan konsumen yang beraneka ragam terhadap desain produk. Masing-masing produk gitar memiliki keunggulan dan keistimewaan masing masing. Hal inilah yang pada akhirnya menyebabkan konsumen dihadapkan pada pilihan yang beragam karena banyaknya produk gitar yang beredar di pasaran dengan keistimewaan masing-masing. Saat ini persaingan gitar sangat ketat sekali, dari model akustik, hingga elektrik.

Perusahaan memiliki keunggulannya masingmasing, ada perusahaan yang unggul di bidang akustik, klasik, dan gitar elektrik. Gitar Aristone ini unggul di bidang gitar akustik, tapi Aristone kalah bersaing dengan kompetitor terdekatnya dalam bidang akustik.

Pada tabel dibawah ini diperlihatkan seberapa besar persaingan yang terjadi antar produk gitar yang beredar di kota Bandung pada tahun 2015, data tersebut diperoleh dari majalah Gitar Plus yang memang cukup mempunyai nama dan memiliki data yang terpercaya dari sejumlah toko di kota Bandung. 


\section{Tabel 1}

Data pangsa pasar Produk gitar di kota Bandung 2015

\begin{tabular}{rlr}
\hline No & Nama Merek Gitar & Pangsa Pasar \\
\hline 1 & Yamaha & $30 \%$ \\
2 & Cort & $19 \%$ \\
3 & Genta & $15 \%$ \\
4 & Aristone & $11 \%$ \\
5 & Allegro & $10 \%$ \\
6 & Caraya & $8 \%$ \\
7 & Lain-lain & $7 \%$ \\
& TOTAL & $\mathbf{1 0 0 \%}$ \\
\hline
\end{tabular}

Sumber: Gitar Plus Ed 141 Desember 2015

Berdasarkan wawancara langsung dan pra riset dengan founder dari produk Aristone dan juga seorang gitaris ternama di kota Bandung yang mewakili pelanggan setia produk Aristone beliau menjelaskan bahwa Produk Aristone yang memiliki desain dan keunggulannya masih cenderung kurang digemari masyarakat kota Bandung karena gitar ini masih kalah dengan produk dari kompetitornya seperti gitar merek Genta, Allegro,dan perusahaan kelas dunia yaitu Yamaha.

\section{Identifikasi Rumusan Masalah}

Berdasarkan latar belakang di atas, maka perumusan masalah yang dapat dirumuskan adalah:

1. Bagaimana kualitas produk gitar Aristone pada CV. Arista Bandung?

2. Bagaimana keputusan pembelian gitar aristone pada CV. Arista Bandung?

3. Seberapa besar pengaruh kualitas produk terhadap keputusan pembelian gitar Aristone Bandung?

\section{TINJAUAN PUSTAKA}

\section{Perilaku Konsumen}

Menurut Sunyoto (2013:1) menyimpulkan bahwa : pemahaman akan perilaku konsumen dapat diaplikasikan dalam beberapa hal, yang pertama adalah untuk merancang sebuah strategi Cort, padahal gitar Aristone ini nyaman dipakai, dan modelnya bisa dipesan sesuai kebutuhan konsumen.

Berdasarkan penjelasan di atas Faktor yang menjadi titik penelitian ini adalah dari segi kualitas produk. Dari penelitian ini juga, dapat diketahui bagaimana kualitas produk dapat mempengaruhi setiap diri pribadi seseorang dalam melakukan proses keputusan pembelian suatu produk.
Pemasaran yang baik, misalnya menentukan kapan saat yang tepat perusahaan memberikan diskon untuk menarik pembeli. Kedua, perilaku konsumen dapat membantu pembuat keputusan membuat kebijakan publik. Misalnya dengan mengetahui bahwa konsumen akan banyak menggunakan transportasi saat lebaran, pembuat keputusan dapat merencanakan harga tiket transportasi di hari raya tersebut Aplikasi ketiga adalah dalam hal pemasaran sosial (social marketing), yaitu penyebaran ide di antara konsumen. Dengan memahami sikap konsumen dalam menghapi sesuatu, seseorang dapat menyebarkan ide dengan cepat dan efektif.

Menurut American Marketing Association atau disingkat AMA (Sunyoto, 2013:2) mendefenisikan perilaku konsumen (consumer behaviour) sebagai interaksi dinamis antara pengaruh dan kognisi, perilaku dan kejadian di sekitar kita di mana manusia melakukan aspek dalam hidup mereka.

\section{Model Perilaku Konsumen dalam Pengambilan Keputusan}

Mempelajari perilaku konsumen bertujuan untuk mengetahui dan memahami berbagai aspek yang ada pada konsumen, yang akan digunakan dalam menyusun strategi pemasaran yang berhasil. Assel (Sunyoto, 2013:81) menggambarkan mengenai model perilaku konsumen dalam pengambilan keputusan sebagai berikut :

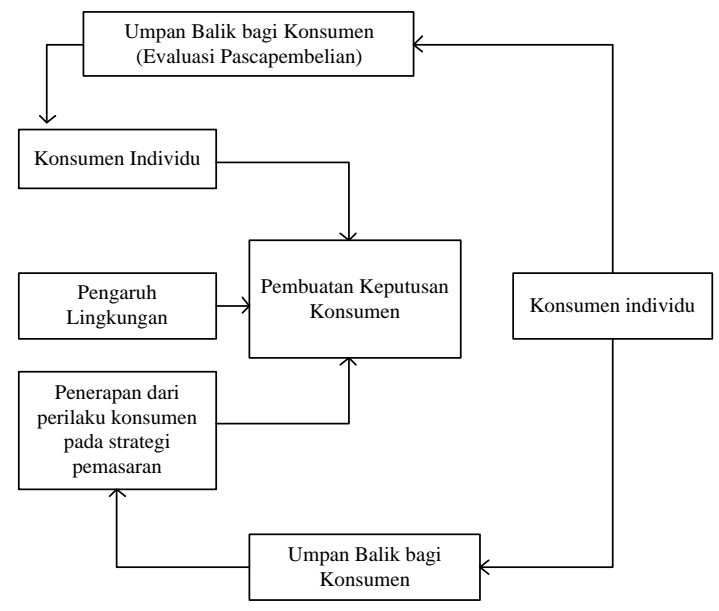

Gambar 1. Model Perilaku Konsumen dalam Pengambilan Keputusan

\section{Proses Keputusan Pembelian}

Keputusan pembelian konsumen merupakan sebuah tindakan yang dilakukan konsumen untuk membeli suatu produk. Setiap produsen pasti menjalankan berbagai strategi agar konsumen memutuskan untuk memberli produknya. 
Menurut Suharno (2010:96), menyatakan bahwa keputusan pembelian Konsumen adalah tahap di mana pembeli telah menentukan pilihannya dan melakukan pembelian produk, serta mengkonsumsinya.

Keputusan pembelian menurut Schiffman dan Kanuk (2010 :437) adalah "the selection of an option from two or alternative choice". Jadi, keputusan pembelian adalah suatu keputusan seseorang dimana dia memilih salah satu dari beberapa alternatif pilihan yang ada.

Kotler dan Armstrong (2009:226) menjelaskan bahwa keputusan pembelian adalah tahap dalam proses pengambilan keputusan pembeli dimana konsumen benar-benar membeli.

Sedangkan Swastha dan Handoko (2008 : 110) mengemukakan bahwa "Keputusan pembelian merupakan proses dalam pembelian yang nyata, apakah membeli atau tidak”.

Berdasarkan definisi dari para ahli diatas disebutkan bahwa keputusan pembelian adalah tindakan yang dilakukan konsumen untuk melakukan pembelian sebuah produk dimana konsumen telah menentukan pilihannya dan benarbenar membeli produk tersebut sesuai keinginannya dengan melalui beberapa tahap seperti pengenalan kebutuhan,pencarian informasi,serta alternative pilihan,setelah itu konsumen dapat menentukan sikap yang akan diambil selanjutnya.

Utami (2012:56), menjelaskan secara umum, konsumen akan melalui lima tahap dalam membeli sesuatu. Adapun tahap-tahap dalam proses keputusan pembelian adalah sebagai berikut:

1. Pengenalan Kebutuhan Pada saat konsumen menyadari adanya kebutuhan yang belum terpuaskan, pada saat itulah mereka berada pada tahap pengenalan kebutuhan.

2. Pencarian Informasi Setelah konsumen mengidentifikasi suatu kebutuhan, maka mereka akan mencari informasi tentang ritel atau produk untuk membantu mencukupi kebutuhan mereka.

3. Evaluasi atas Alternatif-alternatif Setelah mempertimbangkan berbagai faktor sebagai hasil dari proses pencarian informasi, maka konsumen berada pada tahap evaluasi atas alternatif-alternatif yang telah diterapkan oleh konsumen.

4. Keputusan pembelian Keputusan pembelian merupakan keputusan akhir konsumen apakah membeli atau tidak setelah melalui tahap-tahap sebelumnya.

5. Evaluasi Setelah Belanja (Perilaku Pascapembelian) Setelah melakukan pembelian, konsumen menggunakan produk itu dan kemudian mengevaluasi pengalaman ini untuk menentukan apakah produk ini memuaskan atau tidak memuaskan.

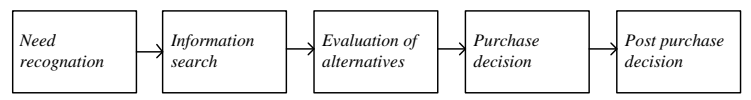

Gambar 2 Tahapan Proses Keputusan Pembelian

Sumber : Principles of Marketing (Kotler \& Keller, 2009, p. 208)

\section{Produk}

Produk adalah segala sesuatu, baik yang bersifat fisik maupun non fisik yang dapat ditawarkan kepada konsumen untuk memenuhi keinginan dan kebutuhannya (Laksana, 2008:67). Konsep produk berpendapat bahwa konsumen menyukai produk yang menawarkan kualitas, kinerja, atau fitur inovatif terbaik (Kotler, 2009:19).

Menurut Nitisusastro (2012:159), konsumen perlu mengetahui tentang karakteristik suatu produk, apabila konsumen kurang mengetahui informasi tentang karakteristik suatu produk bisa salah dalam mengambil keputusan membeli.

Pelaku usaha yang berpengalaman akan memberikan informasi, pendidikan dan kepemahaman kepada setiap calon pembeli khususnya dan kepada masyarakat umumnya.

Menurut Tjiptono (2011:95), produk merupakan segala sesuatu yang dapat ditawarkan produsen untuk diperhatikan, diminta, dicari, dibeli, digunakan, atau dikonsumsi pasar sebagai pemenuhan kebutuhan atau keinginan pasar yang bersangkutan.

\section{Kualitas Produk}

Setiap perusahaan mengharapkan keberhasilan dalam menghadapi persaingan. Perusahaan yang menjadikan pesaing sebagai pembanding dalam menciptakan produk merupakan perusahaan yang baik. Pesaing tidak hanya dijadikan musuh dalam berbisnis karena bisa saja ada sela dan manfaat yang dapat diambil dari para kompetitor tersebut. Seperti dalam menghasilkan produk, produk dari pesaing dapat dijadikan tolak ukur agar produk yang kita hasilkan bisa lebih baik dari produk pesaing dan tentunya memiliki nilai yang lebih unggul.

Tjiptono (2008) memberikan definisi mengenai kualitas yaitu "suatu kondisi dinamis yang berhubungan dengan produk, jasa, manusia dan lingkungan yang memenuhi atau melebihi standar (4 harapan) yang telah ditetapkan".

Sedangkan menurut Garvin dan A. Dale Timpe (1990, dalam Alma, 2011) kualitas adalah keunggulan yang dimiliki oleh produk tersebut. Kualitas dalam pandangan konsumen adalah hal yang mempunyai ruang lingkup tersendiri yang 
berbeda dengan kualitas dalam pandangan produsen saat mengeluarkan suatu produk yang biasa dikenal kualitas sebenarnya.

Berdasarkan beberapa pengertian di atas, kualitas adalah suatu keunggulan yang telah memenuhi standar dan harapan yang telah ditetapkan, sedangkan kualitas produk adalah suatu yang diunggulkan dan ditawarkan perusahaan agar dapat mencapai harapan dan memenuhi kebutuhan pelanggan.

\section{Kerangka pemikiran}

\begin{tabular}{|c|c|}
\hline Kualitas Produk X & Keputusan Pembelian Y \\
\hline $\begin{array}{l}\text { 1. Performance (Kinerja) } \\
\text { 2. Features (Keistimewaan } \\
\text { Tambahan) } \\
\text { 3. Aesthetic (Estetika) } \\
\text { 4. Conformance (Kesesuaian } \\
\text { dengan Spesifikasi) } \\
\text { 5. Durability (Daya Tahan) }\end{array}$ & $\begin{array}{l}\text { 1.Pengenalan Masalah } \\
\text { 2. Pencarian Informasi } \\
\text { 3. Evaluasi Alternatif } \\
\text { 4. Keputusan Pembelian } \\
\text { 5. Perilaku Pasca Pembelian }\end{array}$ \\
\hline Irawan (2009) & Kotler dan Armstrong (2009) \\
\hline
\end{tabular}

Gambar 3 Kerangka Pemikiran Penelitian

\section{Hipotesis}

Berdasarkan landasan teori dan kerangka pemikiran diatas, hipotesis-hipotesis ini ditetapkan sebagai berikut yaitu: "Terdapat pengaruh positif antara kualitas produk terhadap keputusan pembelian gitar Aristone pada CV Arista Bandung",

\section{METODE PENELITIAN}

Penelitian ini menggunakan metode kuantitatif. Menurut Sugiyono (2012: 7), metode penelitian kuantitatif dapat diartikan sebagai metode penelitian yang berlandaskan pada filsafat positivisme, digunakan untuk meneliti pada populasi atau sampel tertentu.

Teknik pengambilan sampel pada umumnya dilakukan secara random, penelitian yang telah dilakukan penulis, gambaran pengumpulan data menggunakan instrumen penelitian, analisis data bersifat kuantitatif/statistik dengan tujuan untuk menguji hipotesis yang telah ditetapkan.

\section{HASIL PENELITIAN DAN PEMBAHASAN}

Berdasarkan responden mengenai Kualitas Produk sudah cukup baik, hal ini terlihat karena mayoritas responden memberi penilaian setuju yang dapat diartikan bahwa responden memberikan penilaian positif mengenai kualitas produk,adapun hal yang perlu mendapat perhatian adalah item mengenai spesifikasi produk karena item tersebut memiliki nilai skor terkecil pada rekapitulasi skor kuesioner mengenai kualitas produk.
Gambaran responden mengenai keputusan pembelian sudah cukup baik hal ini terlhat pada hasil skor rekapitulasi kuesioner sebesar 2089, hasil tersebut dapat diinterpretasikan baik bahwa mayoritas responden memberikan tanggapan yang positif dan dapat diartikan pula responden melakukan tahap demi tahap keputusan pembelian dengan baik pada gitar Aristone.

Mengenai pengaruh kualitas produk terhadap keputusan pembelian dapat dilihat dari hasil uji koefisien determinasi yang menghasilkan kontribusi pengaruh sebesar $52.3 \%$. Hal ini menunjukkan adanya kontribusi dari kualitas produk (X) terhadap keputusan pembelian (Y) sebesar $52.3 \%$, sedangkan sisanya sebesar $47.7 \%$ lainnya diberikan oleh variabel lain yang tidak diteliti oleh penulis seperti promosi, harga, dan lainnya.

\section{KESIMPULAN DAN SARAN}

\section{Kesimpulan}

Berdasarkan hasil penelitian mengenai pengaruh kualitas produk terhadap keputusan pembelian pada produk gitar Aristone di Kota Bandung, melalui observasi, wawancara, dan penyebaran kuesioner terhadap konsumen, maka ditarik kesimpulan sebagai berikut: 1) Tanggapan konsumen terhadap kualitas produk gitar Aristone, mayoritas konsumen mengatakan bahwa kualitas produk gitar Aristone sudah cukup baik dan diharapkan akan terus berkembang di masa yang akan datang, karena sebagian besar konsumen memberikan penilaian yang positif yakni setuju terhadap kualitas produk pada gitar Aristone; 2) Proses keputusan pembelian yang terjadi pada produk gitar Aristone adalah proses keputusan pembelian konsumen yang sempurna. Karena mayoritas konsumen yang melakukan pembelian pada produk gitar Aristone memberikan tanggapan positif yakni setuju melakukan semua tahapan - tahapan dalam proses pembelian dan dalam setiap tahapannya selalu memberikan tanggapan yang positif pula terhadap produk gitar Aristone; 3) Dari hasil perhitungan statistik dengan menggunakan bantuan software SPSS 20.0 for windows didapat bahwa terdapat pengaruh antara kualitas produk terhadap keputusan pembelian sebesar $52.3 \%$, dan sisanya sebesar 47,7 $\%$ dipengaruhi oleh faktor lain yang tidak diteliti oleh penulis seperti promosi, harga, dan lainnya.

\section{Saran}

Berdasarkan kesimpulan yang diperoleh mengenai pengaruh kualitas produk terhadap keputusan pembelian pada produk gitar Aristone, penulis mencoba memberikan saran yang diharapkan dapat bermanfaat dan dapat dijadikan sebagai bahan pertimbangan bagi perusahaan ataupun peneliti lainnya. Adapun saran yang hendak disampaikan, diantaranya: 1) Kualitas Produk. 
Untuk menjadikan produk gitar Aristone semakin baik di mata konsumen, penulis memberikan beberapa saran, yakni: (a) Kepada pihak perusahaan supaya meningkatkan spesifikasi bahan yang akan diproduksi,dan lebih mengenalkan tentang ciri khas,serta keunggulan gitar Aristone kepada masyarakat luas agar konsumen merasa yakin dan tepat telah membeli produk gitar Aristone. (b) Kepada konsumen agar dapat membeli produk asli dalam negeri sehingga menumbuhkan sikap Cinta Produk Dalam Negeri; 2) Keputusan Pembelian. Perusahaan harus terus berusaha meningkatkan kualitas produk dan mengevaluasi tingkat harga yang ditawarkan yang sesuai dengan kualitas produk yang diberikan. Hal itu bertujuan menjadikan konsumen lebih puas akan produk yang dibelinya setelah prilaku pasca pembelian. (a) Kepada pihak perusahaan supaya lebih fokus pada peningkatan kualitas produk, karena berdasarkan hasil penelitian kualitas produk ternyata memiliki pengaruh cukup besar dalam mempengaruhi keputusan pembelian pada produk gitar Aristone di kota Bandung. (b) Dengan besarnya pengaruh kualitas produk terhadap proses keputusan pembelian perusahaan harus memberikan informasi sebaik mungkin terkait spesifikasi produk, performa, fitur, dan daya tahan agar masyarakat tidak ragu untuk memilih gitar Aristone sebagai pilihan utama.

\section{DAFTAR PUSTAKA}

Buchari Alma. (2011). Manajemen Pemasaran dan Pemasaran Jasa. Bandung: Penerbit Alfabeta.

Dwiastuti Rini. dkk. (2013). Ilmu Perilaku Konsumen. UB Press. Malang.

Fajar. Laksana. (2008). Manajemen Pemasaran. Graha Ilmu. Yogyakarta.

Hussein Umar. (2008). Metode Penelitian. CV Alfabeta. Bandung

Kottler, Phillip. (2009). Manajemen Pemasaran Edisi Milenium. Penerbit PT. Prenhallindo. Jakarta.

Kotler dan Amstrong. (2009). Prinsip-prinsip Marketing. Edisi Ketujuh. Penerbit. Salemba.

Kotler, Philip. dan Armstrong. (2009). Dasar-Dasar Pemasaran. Edisi 9. Jilid 1. Alihbahasa : Alexander Sindoro. Jakarta: Penerbit PT Indeks.

Kotler, Philip \& Keller. Kevin Lane. (2007). Manajemen Pemasaran. Edisi 12. Jilid 1. Alih Bahasa : Benyamin Molan. Penerbit PT Indeks. Jakarta.
Lupoyadi. (2013). Pemasaran : Konsep . BPFE Yogyakarta.

Nitisusastro. Mulyadi. (2012). Perilaku Konsumen Dalam Perspektif Kewirausahaan. Bandung: Alfabeta.

Sunyoto. (2013). Manajemen Perilaku Konsumen dan Pemasaran. Jakarta: PT Buku Seru.

Suharno dan Yudi Sutarso. (2010). Marketing in Practice. Yogyakarta: Graha Ilmu.

Schiffman dan Kanuk. (2010). Customer behaviour. Internasional Edition. New York: Prentice Hall.

Sugiyono. (2008). Metodologi Penelitian Bisnis. Cetakan Keduabelas. Bandung: CV. Alfabeta.

Suryani. Tatik. (2008). Perilaku Konsumen. Edisi Pertama. Yogyakarta: Graha Ilmu

Swasta dan Handoko. (2010). Management Pemasaran Modern. Jakarta: Grasindo Persada.

Tjiptono Fandy. (2011). Strategi Pemasaran. Yogyakarta: Penerbit Andi

Tjiptono Fandy. Gregorius Chandra. (2009). Service. Quality \& Satisfaction Edisi 3. Jakarta: Andi

Utami. (2012). Perilaku Konsumen. Jakarta: Mitra Utama. 